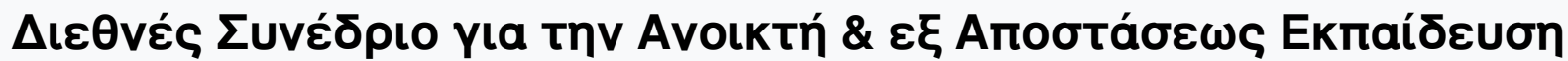

Tóp. 10, Ap. 3A (2019)

\section{ПPAKTIKA}

$10^{C}$ EYNEAPIO TIA THN ANCIKTH \& E AחCETALERI EKMAIAEYLH

를

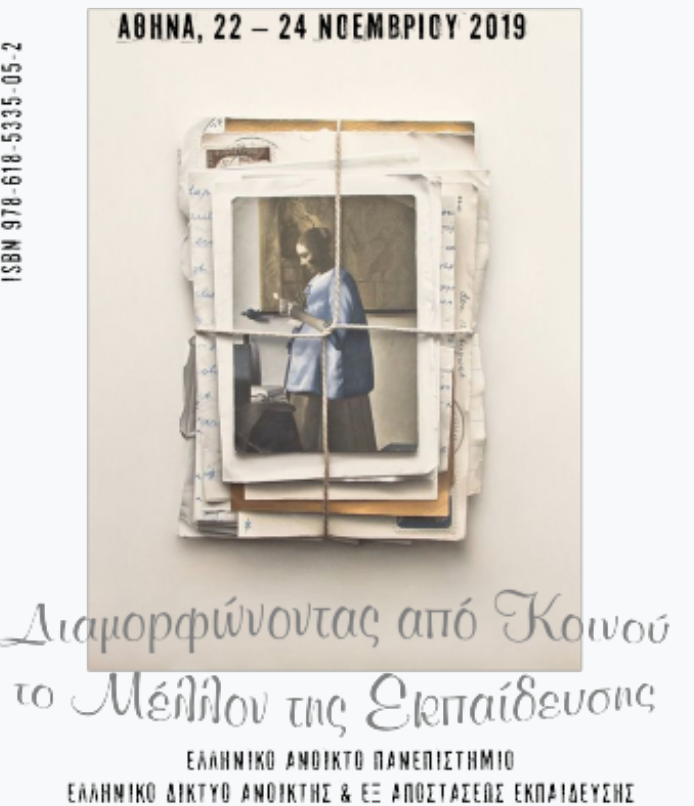

'Invitation to a party'. A Task-Based Second Language Learning and Teaching with Technology scenario for Greek language adult learners

Athanasia Angeli

doi: $10.12681 /$ icodl.2366

\section{TOMOL 3, MEPOLA}




\title{
'Invitation to a party'. A Task-Based Second Language Learning and Teaching with Technology scenario for Greek language adult learners
}

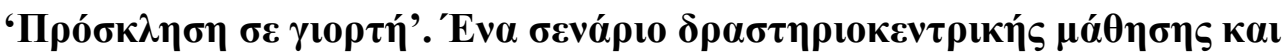

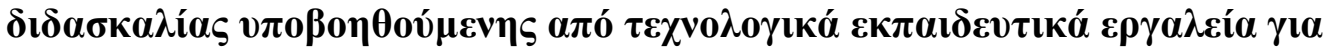

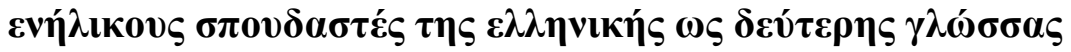

\author{
Angeli Athanasia \\ M.Ed., PhD candidate \\ Hellenic Open University \\ 8aggeli@gmail.com
}

\begin{abstract}
In this Essay a 5 hour teaching scenario entitled 'Invitation to a party' is presented. It is designed for adult migrants and refugees, A2 -by CEFRL standards- Greek language learners at a non-formal learning setting in Athens, Greece. This blended educational scenario is based on sociocultural, constructivist, and Computer Assisted Language Learning (CALL) approach. It aims to enhance the learners' communication skills (communicative, sociocultural, metacognitive, language and cultural awareness) through Task-based language learning (TBLL) activities integrating digital tools, such as Padlet, Office Forms, WordCloud and Canva. The added value of this scenario is that on the occasion of organizing a celebration, a situation that unites people all around the world, learners are supposed to develop simultaneously their L2 competencies, their digital skills and their citizenship, investing actively their identity. Through communication, creativity and collaboration supports learners to be creators of knowledge.
\end{abstract}

Key-Words: Task-Based Language Learning and Teaching (TBLL-TBLT), Computer Assisted Language Learning (CALL), Greek Language Learning for Migrants and Refugees, Greek as L2

\section{Пєрі́ $\eta \psi \eta$}

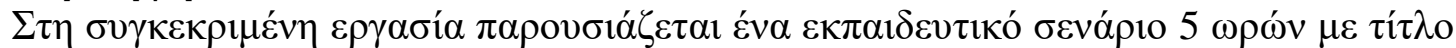

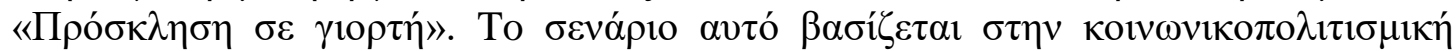

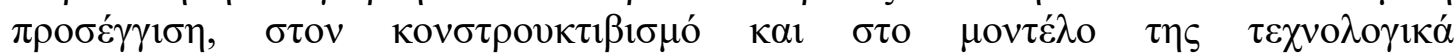

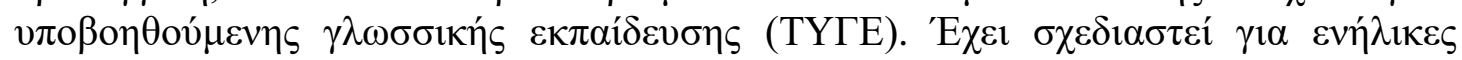

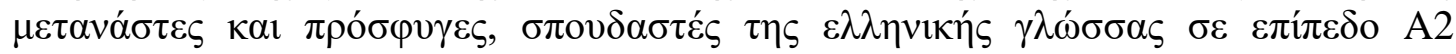

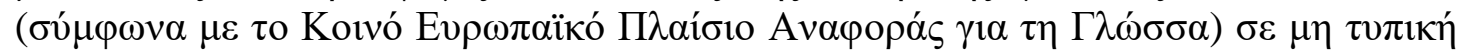

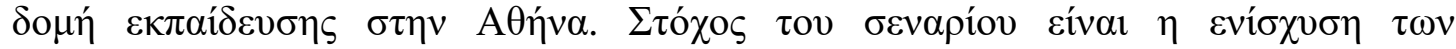

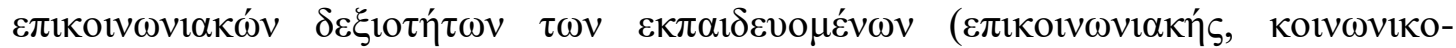

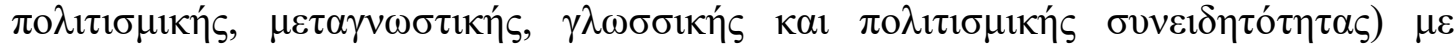

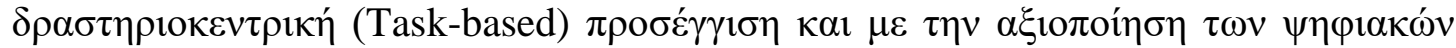

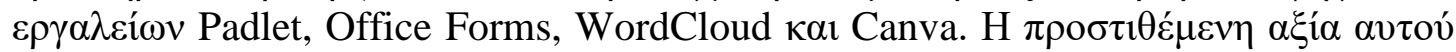

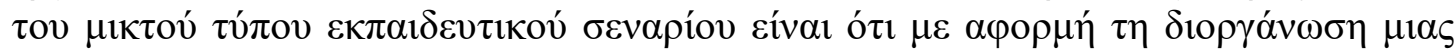

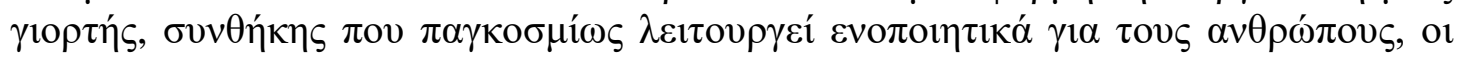




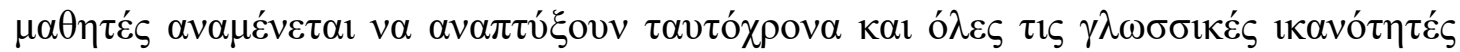

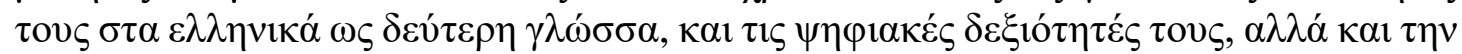

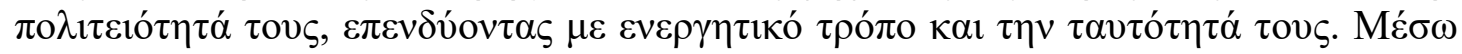

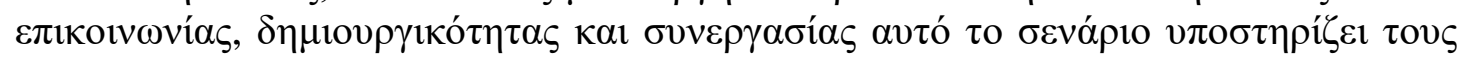

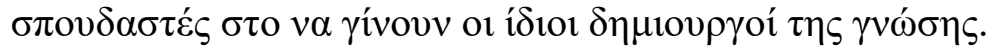

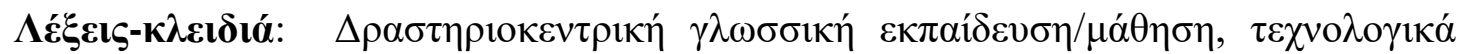

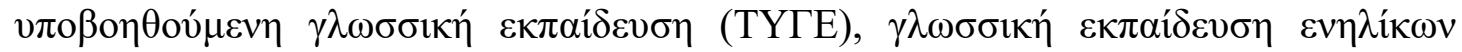

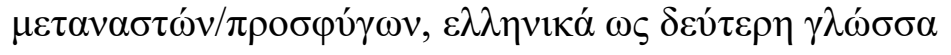

\section{The educational audience and context}

This educational scenario is designed for a particular audience of ten young adult learners (21-30 years old, half women-half men) of migrant and refugee background, from Egypt, Iraq, Syria and India, living in Athens for at least two years. They are High school and University graduates, digital natives (Prensky, 2009) and their English language competency (according to their statement) is B1 level, while their Greek language level of proficiency is A2 according to CEFRL. Their heterogeneity stems from both their country of origin, spoken languages, wider sociocultural background and prior educational experiences, as well as their diverse migratory trajectories and future residence plans (Vertovec, 2007).

The educational context of this scenario is the non-formal educational program for adult refugees and migrants implemented free of charge by a non-formal educational center in Athens, including Greek and English language courses and IT courses. Hence, the classroom is equipped with computers corresponding to the number of learners.

\section{The design rationale}

The main goal of this scenario is integrating digital technology to ameliorate the communicative skills of the learners through collaboratively creating a party invitation that will eventually take place in the learning center's educational framework.

More specifically, considering their sociolinguistic profile and in accordance to A2 level of Common European Framework of Reference for Languages (CEFR) (European Union, 2001; Council of Europe, 2014; Beacco, Krumm, and Little, 2017), this scenario aims to enhance the communicative competences of the learners, i.e. linguistic ("lexical, grammatical, semantic, phonological, and orthographic"), sociolinguistic (in order to "handle linguistic markers of social relations, politeness conventions" and everyday expressions) and pragmatic ("discourse and functional”) (Little, 2012, p.4) concerning social events such as a party in Greece. These learning objectives are further specified in the following section of the same name.

The Communicative Language Teaching (CLT) approach, which emphasizes simultaneously on linguistic and communicative competencies and focuses on process, using authentic and meaningful purposeful activities (Littlewood, 1981; Rodgers,2009) seems to be more effective for the second language learning (SLL) of this group of refugees and migrants in the aforementioned framework of non-formal multicultural adult education (Gorsky, 1995-2018).

Furthermore, Task-based language teaching (TBLT), one of the science-research supported communicative approaches, is chosen because it is contextualized, learnercentered, and analytic and can serve communicative, sociocultural, metacognitive and language and cultural awareness goals (Nunan, 2004) through various types of 'tasks' 
(Ellis, 2009, Nunan, 2004, Rodgers, 2009). Six activities have been designed in three ('pre'-, 'main', and 'post'-task) phases in order to lead to a meaningful transformation of the input, enhancing learners' active, creative, reflective and finally autonomous language use as well as expanding their metacognitive awareness by promoting selfassessment and programming next steps in language learning (Nunan, 2004). By all means, this TBLL scenario is clearly distinct from the traditional teacher-centered 'presentation-practice-production' (PPP) model (Ellis, 2009; Willis, 1996).

Additionally, in this scenario TBLL interconnects the educational framework with the social context, the pedagogical with the real-world tasks, expanding language learning beyond the classroom with the support of Web 2.0 technology (Beatty, 2010; Thomas \& Reinders, 2010; Kourti-Kazouli, 2015). This blended model of Computer Assisted Language Learning (CALL) seems to correspond to the educational needs of refugee and migrant adult learners (Griffith \& Wong, 2010; Leung, Lamb, \& Emrys, 2009). It promotes their autonomy and emphasizes on their communicative skills towards academics (Cummins, 2008), through their interaction not only with technological means (Beatty, 2010), but also with each other (for example, with students from other countries) and natural speakers of the language, in the context of constructivism and cooperative learning (Lantolf, 2000). Hence, incorporating "the $3 \mathrm{Cs}-$ communication, creativity and collaboration into teaching and learning" (Jarvis, 2015) allows learners to be "communicators, commentators," and most of all, "creators" of knowledge, which is no longer "in the hands of the few" (Jarvis, 2015).

The digital tools used are:

(a)'Padlet.com' (<https://padlet.com/>), a digital table where learners and trainers can post notes, combining the advantages of a blog "with wikis' or Google-docs' more collaborative use" (Blake, 2016, p.136). It is accessible from any device, does not require personal accounts or downloading any application and supports both synchronous and asynchronous communication. The degree of publicity and of user intervention to the original content, as well as the background theme and the layout can be adapted, depending on the educational goals (Fuchs, 2014; Nagamani, 2017). Most importantly, Padlet is available in Greek, which is the target language in this scenario.

(b)WordClouds( $<$ https://www.wordclouds.com/ $>$ ): It is used for the visual representation of a text, supporting higher order thinking skills, knowledge management and representation. This particular program was preferred due to its free access and availability in Greek. Also, because it can guide the novices in its creation (e.g. how to upload text and documents in various formats or change size and colours) with its 'Wizard' selection (Johnson, 2016).

(c) Canva (<https://www.canva.com>) is a graphic design program of free access in this version, very easy to use and supported by printable design templates, which -most importantly- can both individually or collaboratively be modified and adapted to their users' creative needs.

(d) Microsoft Forms (<https://support.office.com/en-us/forms $>$ ) can be used independently or collaboratively in groups to create free of charge (in this edition) questionnaires, quizzes, surveys, and polls in a few easy steps, choosing the background and the form of the answers (e.g. choosing between preset options, filling text, rating etc.) 


\section{The Learning objectives}

At the completion of this imaginary 5 hour TBLL lesson, integrating digital tools, and subject to a prior thorough objective and subjective needs analysis (Van Avermaet, \& Gysen, 2008), students are expected (Churches, 2008; Olinghouse, 2008):

1. Supported by authentic visual stimuli (e.g. pictures of various types of parties), to name, recall and reproduce at least ten words related to celebrations (e.g. giorti, trapezi, mpoufes, xoros, mousiki, nixterino kentro, diakosmisi, kosmos) and three everyday expressions used for birthday wishes (e.g. 'xronia polla', 'na ta ekatostiseis', 'polyxronos/-i', 'na xairesai ton/tin ...') (Tasks 1, 2, 6) (Writing)

2. To write a short text describing a personal experience of a festive social gathering from their home country using basic vocabulary and syntax. (Task 1) (Writing)

3. To recognize and understand key words and simple sentences including politeness conventions concerning parties in texts, posters, invitations. (Task 4) (Reading)

4. To ask and respond correctly (to) simple questions (e.g. what, who, when, why) on the specific topic in order to collaboratively produce an infographic presenting their small group ideas. (Tasks 2,3) (Spoken production and Writing)

5. To exchange information, opinions, interests, preferences and feelings orally and argue in favor of their choice following the required for the particular communicative situation linguistic rules. (Tasks 2,3) (Spoken production)

6. To interact in a simple way, helping each other formulate what they are trying to say scaffolding peer learning. (Tasks 2, 3) (Spoken Interaction)

7. To understand familiar words and very basic phrases concerning daily communication and friendly relationships when people speak slowly and clearly about a party. (Task 2,3) (Listening)

8. Identify and relate each other's and the hosting country's social habits and social practices for festive social gatherings and particularly for school and birthday parties (Tasks 1, 3, 4) (Sociocultural awareness)

9. Conclude the form-function relationships necessary for the completion of the highly contextualized and communicative nature of this TBLT scenario. (Selfevaluation activity) (Metacognitive skills)

10. Reflect on their own learning and on the role of the particular TBLT unit. Evaluate their strong and weak practices. Plan their own next steps on their Greek SLL. (Self-evaluation activity) (Metacognitive skills)

11. Employ the proposed digital tools effectively (Digital skills)

\section{Activity flow}

\subsection{Task 1: What do you see? Describe the pictures $\left(3^{\prime}\right)$}

\section{Goal}

1. Describing one of the pictures

2. Writing a short Padlet post.

\section{Rationale}

This introductory stage aims to introduce the topic and provide visual stimuli to activate learners' prior relevant language repertoire. The collaboratively highlighted nouns, 
verbs and phrases (refering to different places, time, activities and goals of a celebration) will be used as supporting language input (key vocabulary or grammatical issues) for the next steps of the scenario. Furthermore, the participants are encouraged to connect learning to their personal experiences and feelings, sharing crosscultural knowledge.

\section{Description and procedure}

The educator uses Padlet (https://padlet.com/8aggeli/mathaino_ellinika) to create a Unit entitled 'Everyday life - social events' and shares the link of the page with the learners. She uploads five authentic pictures of different types of celebrations found on the internet and asks learners to write in the next 15 minutes a short text in order to describe one of them and state their thoughts and/or feelings in the form of a 'Comment'. They are also invited to comment on each-others posts (Figure-1). Key vocabulary and grammatical issues will be addressed collaboratively in a class plenary session.

The communicative demand of this activity is medium due to the communicative stress deriving from the time pressure, while the required interaction is high with computer mediated communication (CMC) (Zhang, 2012), writing and discussion.

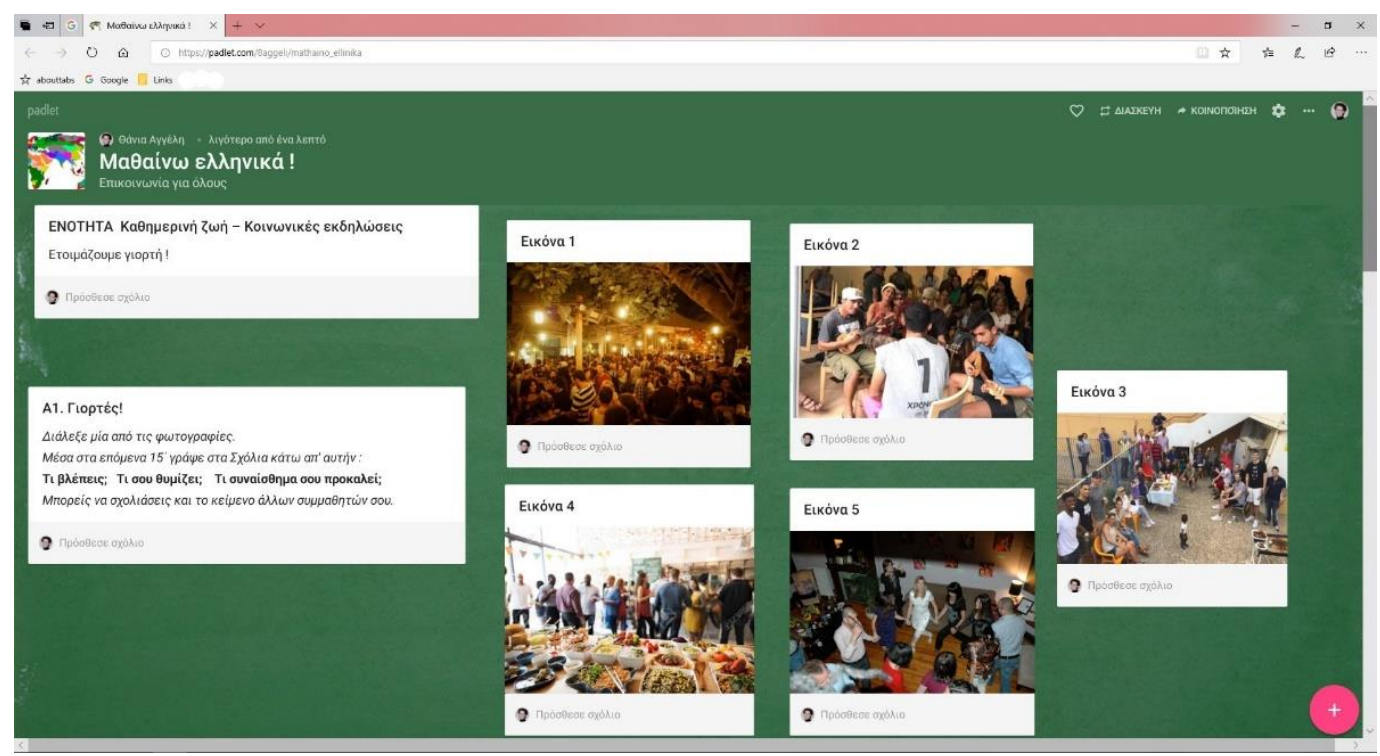

Figure-1: Task 1: What do you see? Describe the pictures

\subsection{Task 2: The school celebration I prefer $\left(45^{\prime}\right)$}

\section{Goal}

1. Discussing in pairs about the preferable school party

2. Collaboratively creating a word cloud representation

3. Presenting the art-craft orally in the class

\section{Rationale}

This activity aims to motivate learners to recall and reproduce creatively the vocabulary related to celebrations which was produced in the previous activity, to argue orally advocating their personal favorite school celebration and, hence, collaboratively produce a shared short written text using future tense verbs and expressions. Finally, to develop their digital skills using WordClouds (https://www.wordclouds.com/) to create their own art-craft transforming the aforementioned text into an image. This activity is 
expected to enhance learners' higher thinking skills and to be appealing particularly to visual learners.

\section{Description and procedure}

The teacher posts on Padlet thorough details of the aforementioned procedure. Students have to respond by uploading their art-crafts (Figure-2) and being prepared to present them orally in the class.

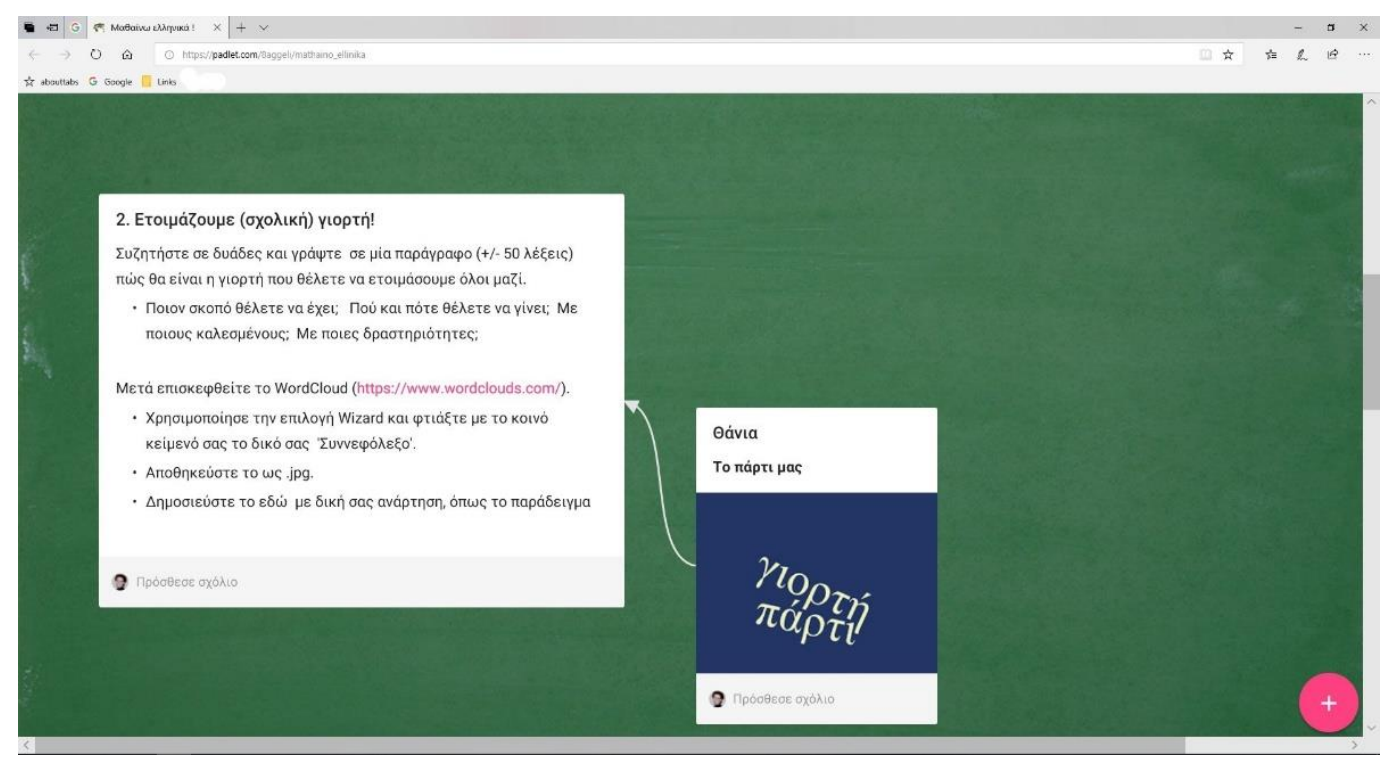

Figure -2: Task 2: The school celebration I prefer

\subsection{Task 3: Invitation to our school party! $\left(45^{\prime}\right)$}

\section{Goal}

1. Discussing in pairs about the form and the content of the invitation to the school party

2. Collaboratively create an infographic of the invitation to the school party.

3. Presenting the art-craft orally in the class

\section{Rationale}

The aim of this main-task is learners to communicate orally and develop their critical and cultural awareness asking, answering, and arguing about their preferences both in dyads and (later) in the plenary session. Additionally, to develop their digital skills using the particular digital tool (Canva).

The cognitive complexity of this activity is low as students state their personal preferences. Nevertheless, its communicative demand is high due to the need of generating ideas and exchanging of views as well as the need of collaboration to draw the assigned infographic.

The collaborative and divergent type of this synchronous computer-mediated task provides opportunity for increased language production and conscious reflection, while the dyadic interaction leads to equal and active participation and ensures peer learning. Furthermore, the outcome with its written form allows individualized follow-up (Zhang, 2012). 


\section{Description and procedure}

During this activity students in dyads collaboratively design their invitation to their preferable school party using https://www.canva.com and its templates to create their infographic, which they post to the Padlet page. Finally, they vote through Padlet for the best 'invitation' and then they present their art-craft and choice orally in the class (Figure-3). The teacher gives feedback on the content and quickly reviews what is suggested.

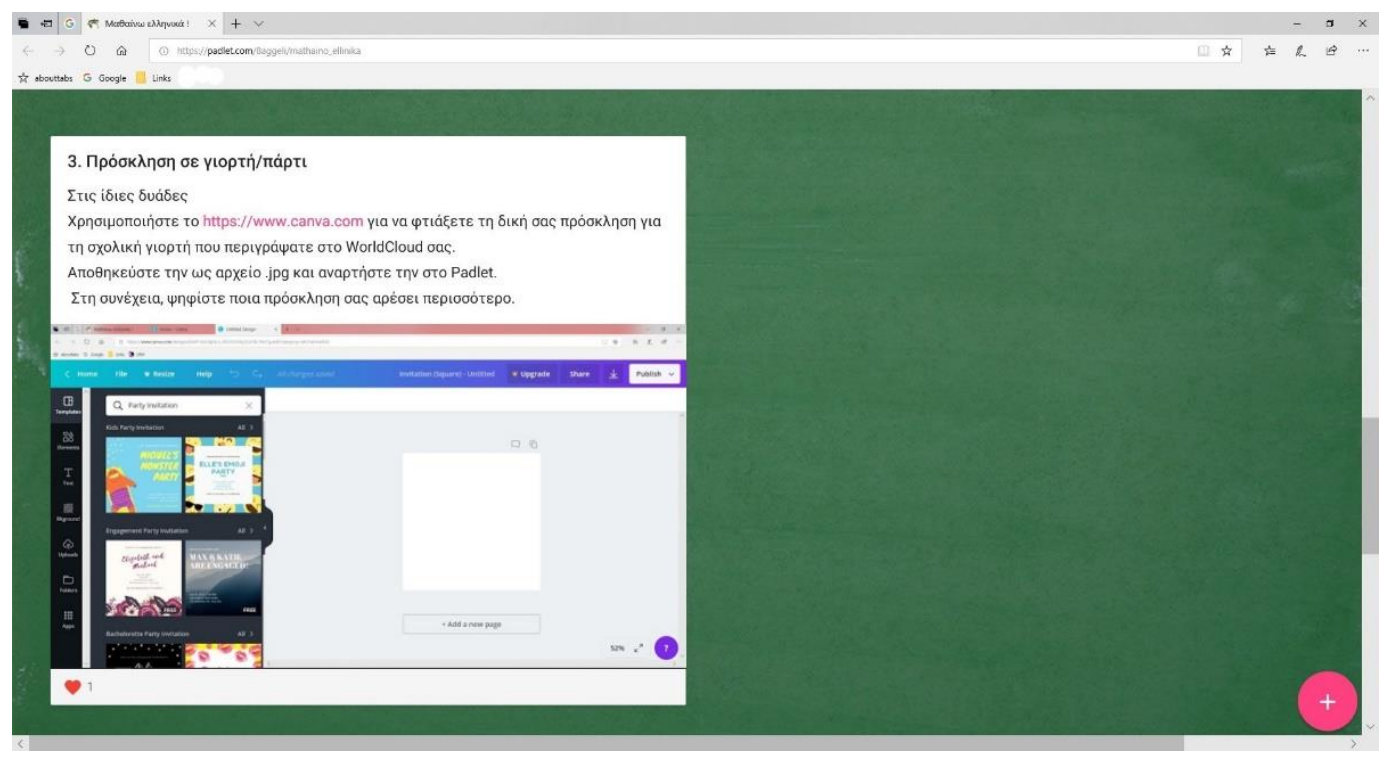

Figure -3: Task 3: Invitation to our school party!

\subsection{Task 4: Reading Comprehension (25')}

\section{Goal}

1. Finding the correct answer to Reading Comprehension Questions.

2. Filling the digital form and submitting it to the tutor

\section{Rationale}

During this post-task stage, according to TBLT principles, supporting students' learning autonomy, the class finally focuses on language form. The aim of this activity is to reassure that students can recognize the new vocabulary referring this time to a birthday party and they can identify the meaning of everyday expressions used for birthday invitations. Furthermore, depending on the observed weaknesses, the tutor highlights vocabulary items and communicative forms necessary to make suggestions, conclusions etc. concerning the subject of the invitation to a birthday party.

\section{Description and Procedure}

Students are asked to read a text uploaded in the Padlet as a .pdf file concerning the dialogue of an invitation for a birthday party, and then, using https://forms.office.com/ to answer reading comprehension questions and submit them individually to their tutor (Figures 4 \& 5). 


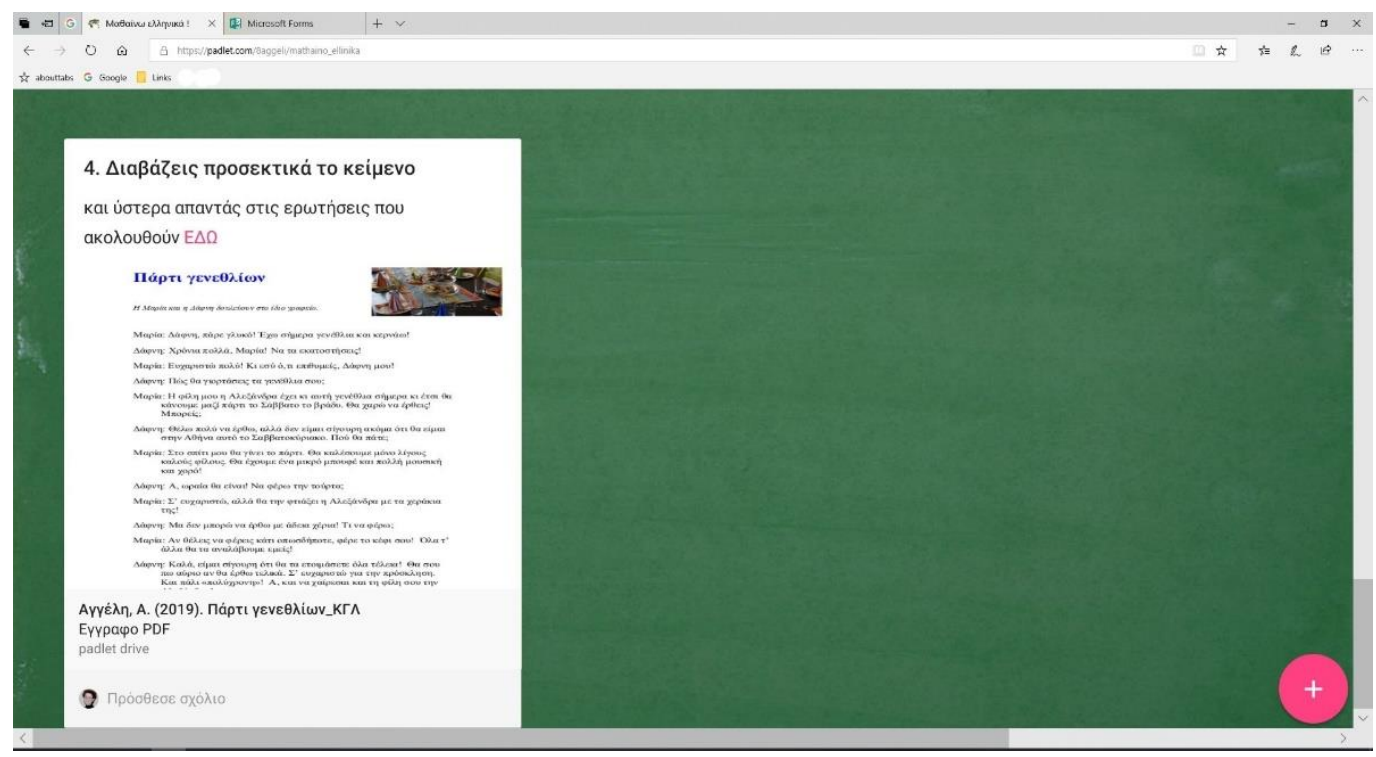

Figure -4: Task 4: Reading Comprehension Text

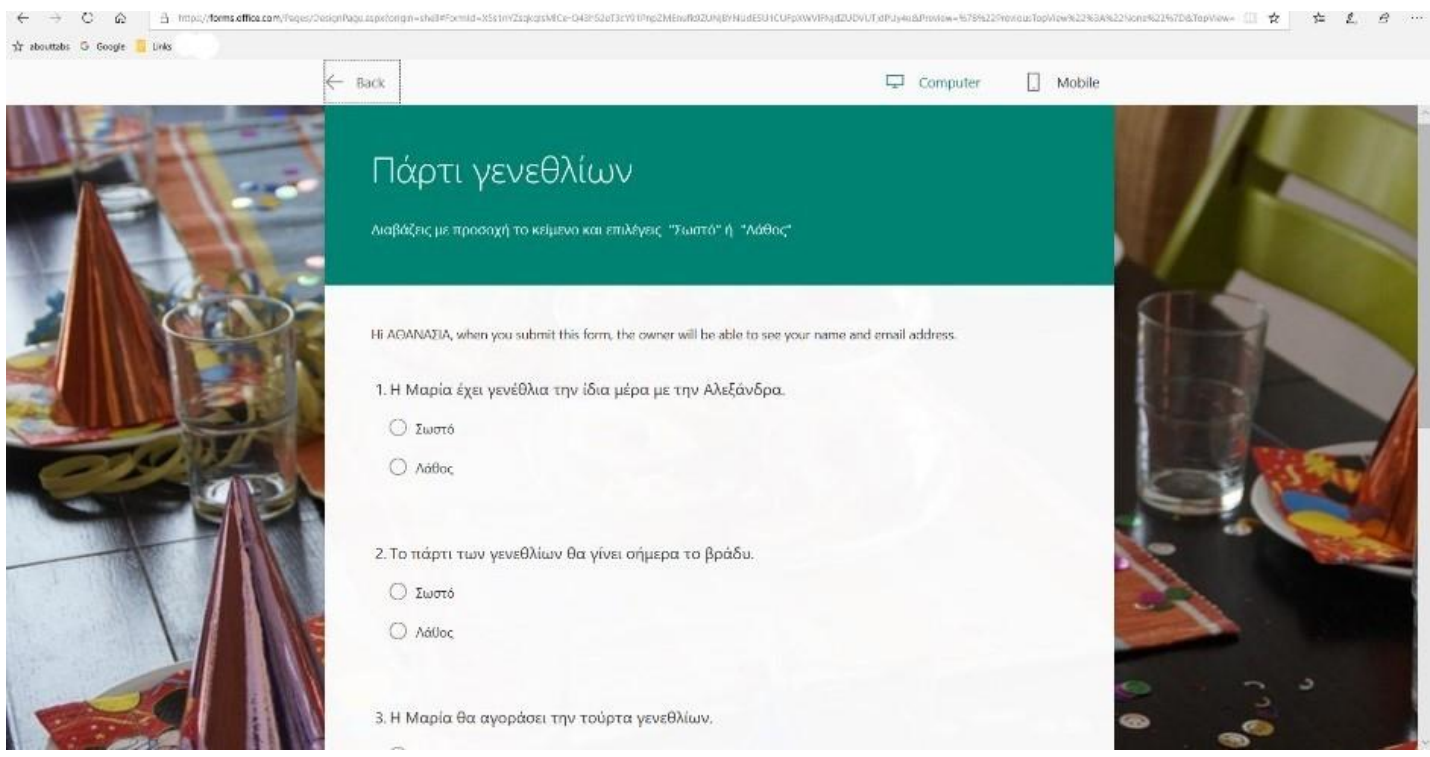

Figure -5: Task 4: Reading Comprehension - Office Forms

\subsection{Task 5: Help Alexandra complete her e-mail! (20')}

\section{Goal}

1. Contextual use of grammar types (future expressions).

2. Filling the text in the digital form and submitting it to the tutor

\section{Rationale}

Further focusing on form, this activity emphasizes on grammar items concerning future expressions (future tense and subjunctives). This activity contextualizes the use of the particular grammar phenomena and serves as a formative assessment tool. 


\section{Description and Procedure}

At this stage students are asked to use https://forms.office.com/ in order to fill the correct form of the verbs (future tense and subjunctives) in the e-mail that is supposed to be sent to a friend to inform him/her of the aforementioned birthday party (Figures $6 \& 7)$.

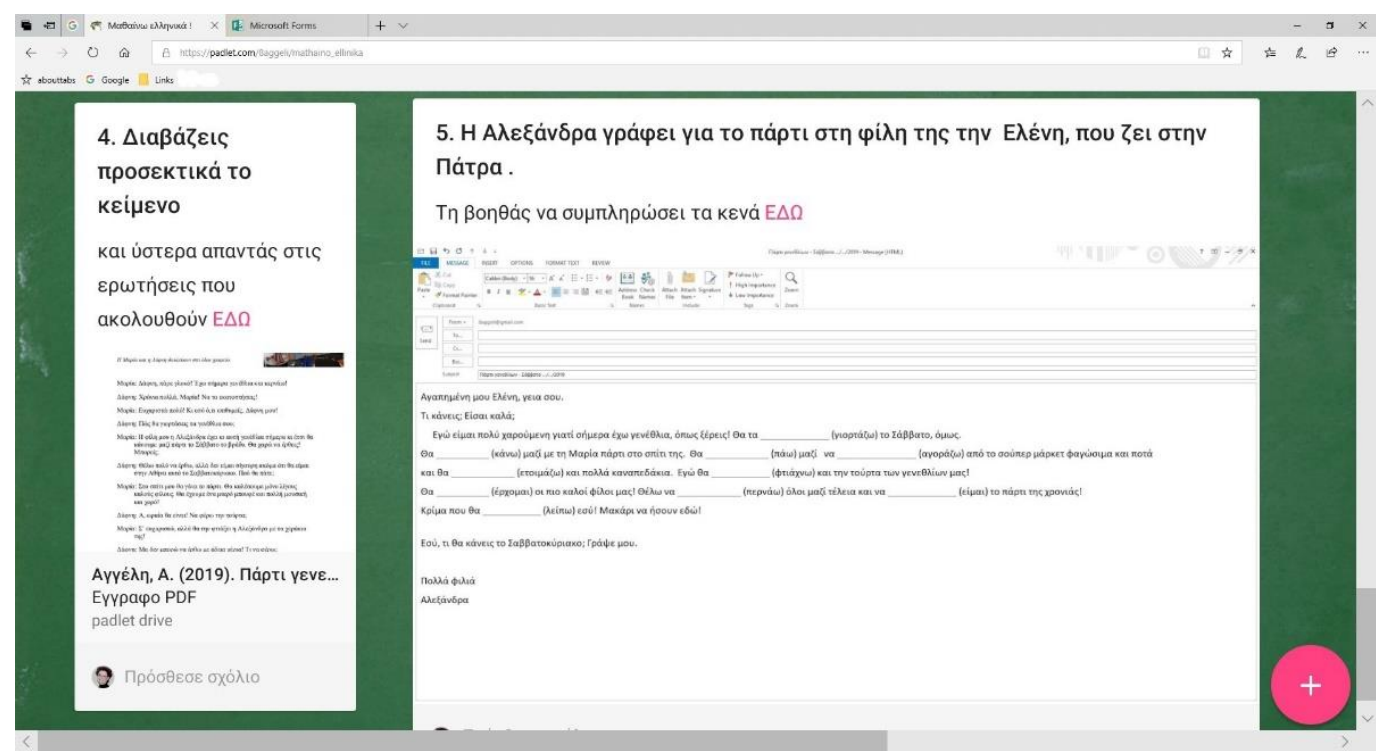

Figure -6: Task 5: Help Alexandra complete her e-mail!

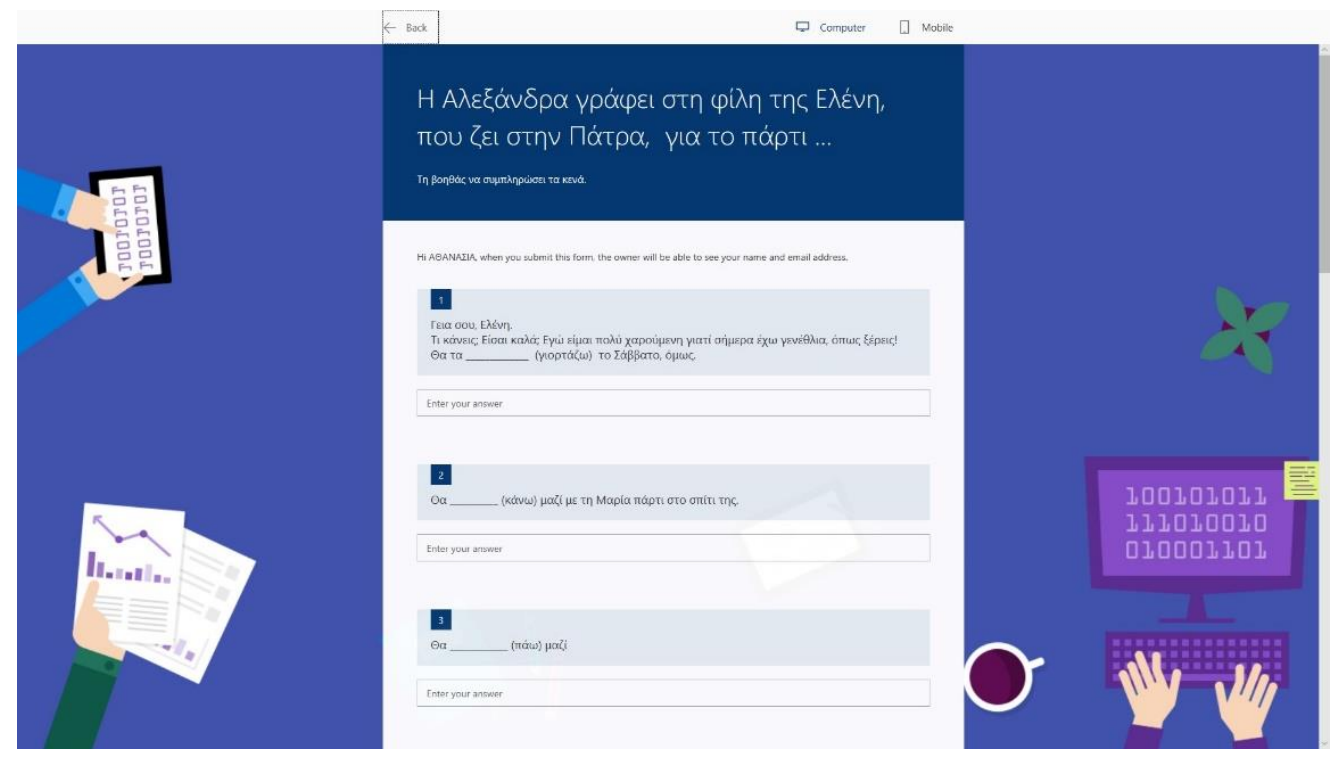

Figure-7: Task 5: Help Alexandra complete her e-mail! - Office Forms

\subsection{Task 6: Invite your friend(s) to our school party! $\left(60^{\prime}\right)$}

\section{Goal}

1. Writing an e-mail to invite friends to the school party.

2. Organizing the actual party 


\section{Rationale}

The purpose of this concluding activity is to enhance students' writing skills asking them to creatively reproduce the new vocabulary and grammar already used in the previous tasks. The outcome will be included in their learning portfolio and it serves as a formative assessment tool, which can develop their self-esteem and awareness and further trigger their motivation for learning.

\section{Description and Procedure}

Students are asked to use previous tasks' results and the provided educational material to write an invitation to the forthcoming school party to a special friend of theirs by email (Figure-8) and submit it to the tutor via Padlet within 30'

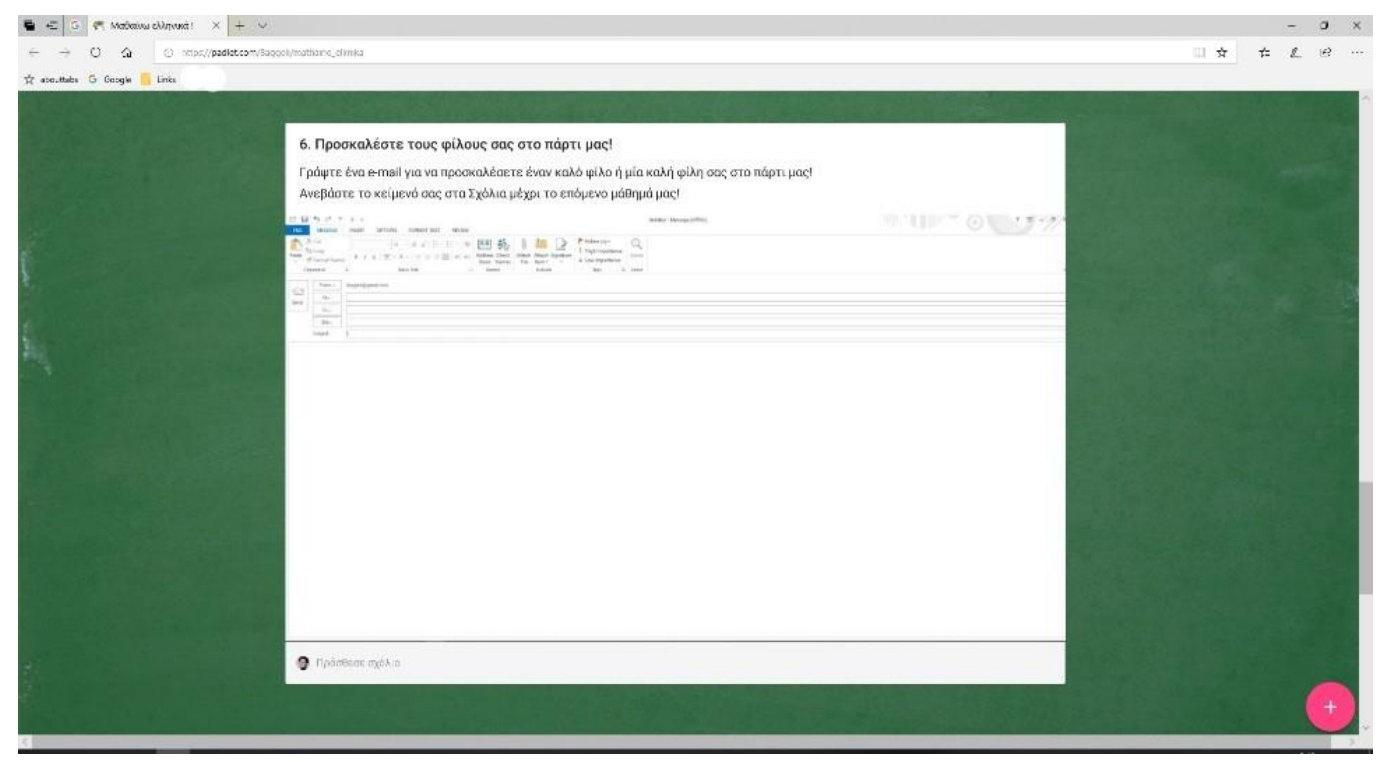

Figure -8: Task 6: Invite your friend(s) to our school party!

During the following plenary session $\left(30^{\prime}\right)$ they are invited to get prepared for the next steps of the project in order to organize the actual party chosen by the majority of the students in the previous tasks. This serves as the pre-task stage of the next TBLT lesson plan.

\section{Evaluation}

During this educational scenario there is a process evaluation. Thus, Task 1 acts as a diagnostic tool for learners' educational needs in terms of vocabulary and grammarsyntactic phenomena, as well as their cultural and cross-cultural awareness. Additionally, content analysis of their digitally mediated communication provides the tutor with data about the social presence and the quality of the interaction (the degree of the affection and the cohesion), considering factors such as the media affordances, the task type and the group dynamics (Thomas \& Reinders, 2010). Furthermore, Posttask activities such as Tasks 4, 5, 6, allow monitoring of the language skills acquired by the learners and plan further focus on accuracy if necessary (Zhang, 2012).

Finally, supporting their autonomy and accountability, learners are asked to fill the selfevaluation form uploaded in a Word-document format to Padlet (Figure-9), determining themselves their own goals and achievement(s) in the first column of the table. Besides, 
their learning pathway is highly influenced by their own perceptions and personal goals (Kumaravadivelu, 2009).

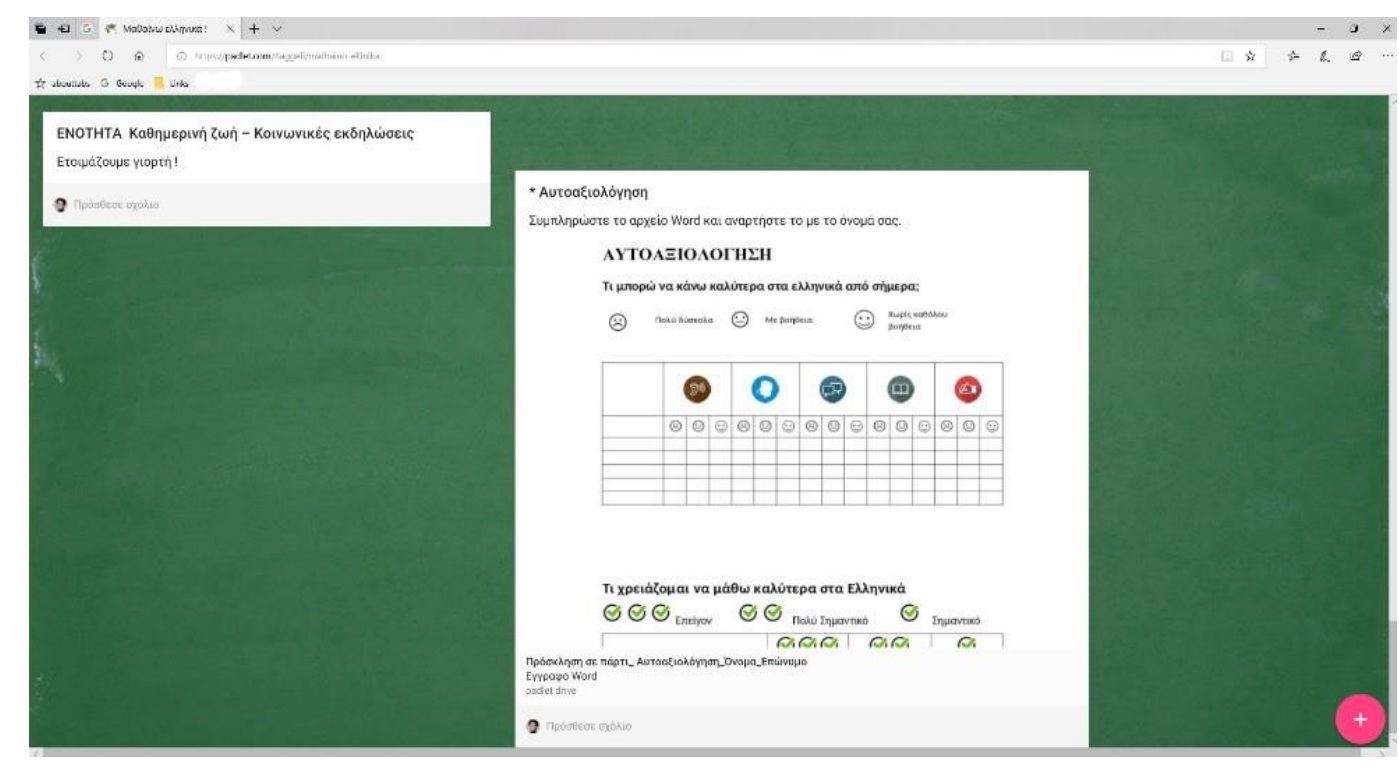

Figure -9: Self-evaluation form

\section{Discussion}

In the context of globalization and concurrent multicultural societies, the constantly increasing flows of migrants and refugees elicit the need to meet their communication needs both as a precondition for their own survival and prosperity and for the benefit of the host society (Van Avermaet, \& Gysen, 2008).

Hence, the most obvious added value of this educational scenario is the TBLT approach: with its universally interesting theme of festive social gatherings and the transformation of real-world tasks into pedagogical ones, it can facilitate identity investment and intercultural approach (Norton, 2006). Furthermore, integrating digital technology for educational -yet playful- activities designed for a group of young adult migrants and refugees is expected to address their multiple intelligences and draw their enthusiasm (Hazari, North, \& Moreland, 2009) and, hence, foster their active, collaborative participation and their long-term commitment to the goals of the educational program. Finally, its most important novelty, especially for the Greek educational framework, is exactly this synergy of TBLT and CALL (Jarvis, \& Krashen, 2014), which can ensure the enhancement of the comparative advantages of both approaches, developing learners' $21^{\text {st }}$ century skills (Luna Scott, 2015).

The additional fact that free open source and easy to use -especially by digital native learners- educational tools have been selected, makes this student-centered educational scenario realistically applicable. That is why the last challenge is actually to be implemented to either confirm the expectations for its effectiveness or to make possible adjustments. Then, it can be used by other educators, obviously with the compulsory adaptations to the respective educational framework and the particular educational needs of each group of learners. 


\section{References}

Beacco, J.-C., Krumm, H.-J., and Little, D. (2017). Introduction. In J.-C., Beacco, H.-J., Krumm, D., Little, and Ph. Thalgott, (Eds). The Linguistic Integration of Adult Migrants. Some Lessons from Research. Council of Europe.

Beatty, K. (2010). Teaching \& Researching: Computer-Assisted Language Learning. (2nd Ed.) New York, USA: Routledge (First edition 2003 London, UK: Pearson Education ESL).

Blake, R. (2016). Technology and the four skills. Language Learning \& Technology, 20(2), 129-142.

Churches, A. (2008). Bloom's digital taxonomy. Retrieved from http://burtonslifelearning.pbworks.com/f/BloomDigitalTaxonomy2001.pdf

Council of Europe (2014). The linguistic integration of adult migrants: from one country to another, from one language to another. Retrieved from https://rm.coe.int/16802fd54a

Cummins, J. (2008). BICS and CALP: Empirical and Theoretical Status of the Distinction In B.Street, \& N. H. Hornberger, (Eds.). (2008). Encyclopedia of Language and Education, 2nd Edition, Volume 2: Literacy. (pp. 71-83). New York: Springer Science + Business Media LLC.

Ellis, R. (2009). Task-based language teaching: Sorting out the misunderstandings. International Journal of Applied Linguistics, 19(3), 221-246.

European Union (E.U.) (2001). Common European Framework of Reference for Languages: learning, teaching, assessment: case studies. Council of Europe.

Fuchs, B. (2014). The writing is on the wall: using Padlet for whole-class engagement. LOEX Quarterly, 40(4), 7.

Gorski, P. C. (1995-2018). Stages of Multicultural Curriculum Transformation. Retrieved from http://www.edchange.org/multicultural/curriculum/steps.html

Griffith, M., \& Woong, L. (2010). Empowering adult learners through blog: An Australian case study. In T., Kidd, \& J. Keengwe, Adult learning in the digital age: perspectives on online technologies and outcomes (pp. 13-22). IGI Global.

Hazari, S., North, A., \& Moreland, D. (2009). Investigating pedagogical value of wiki technology. Journal of Information Systems Education, 20, 2.

Jarvis, H. (2015). Computer Assisted Language Learning today: a critique. British Council Seminars. Retrieved from http://englishagenda.britishcouncil.org/seminars/beyond-computer-assistedlanguage-learning

Jarvis, H., \& Krashen, S. (2014). Is CALL Obsolete? Language Acquisition and Language Learning Revisited in a Digital Age. TESL-Ej, 17(4), 1-6.

Kourti-Kazoulli, V. (2015). Technologika Ypovoithoumeni Glossiki Ekmathisi: Efarmoges stin Ellada In E.Skourtou, \& V.Kourti-Kazoulli (Eds). Diglossia kai didaskalia tis Ellinikis os Defteris Glossas. SEAV.

Kumaravadivelu B. (2009). Learner Perception of Learning Tasks. In Van den Branden, K., Van Gorp, K., \& Verhelst, M. (Eds.) (2009). Tasks in action: Task-based language education from a classroom-based perspective. Newcastle, UK: Cambridge Scholars Publishing.

Lantolf, J. P. (Ed.). (2000). Sociocultural theory and second language learning (Vol. 78, No. 4). Oxford University Press.

Leung, L., Lamb, C. F., \& Emrys, L. (2009). Technology's Refuge. The Use of Technology by Asylum Seekers and Refugees. Sydney: UTS ePress.

Little, D. (2012). The linguistic integration of adult migrants and the 'Common European Framework of Reference for Languages'. Strasbourg: Council of Europe.

Littlewood, W. (1981). Communicative language teaching: An introduction. Cambridge University Press.

Luna Scott, C. (2015). The Futures of Learning 3: what kind of pedagogies for the 21st century?. UNESCO

Nagamani, B. (2017). Padlet: A Collaborative Language Teaching and Learning Tool. Journal of technology for ELT. 7(2)

Norton, B. (2006). Identity as a sociocultural construct in second language research. TESOL in context [special issue], 22-33.

Nunan, D. (2004). Task-Based Language Teaching. University of Hong Kong. Cambridge University press.

Olinghouse, N. (2008). Designing Lessons for Diverse Learners. Retrieved from http://education.msu.edu/te/secondary/pdf/Designing-Lessons-for-Diverse-Learners.pdf

Prensky, M. (2009). H. sapiens digital: From digital immigrants and digital natives to digital wisdom. Innovate: journal of online education, 5(3), 1. 
Rodgers, T. S. (2009). The methodology of foreign language teaching: Methods, approaches, principles. In K., Knapp \& G. Antos (Eds.), Handbook of foreign language communication and learning (pp. 341-373). Berlin: Mouton de Gruyter.

Thomas, M., \& Reinders, H. (Eds.). (2010). Task-based language learning and teaching with technology.Continuum International Publishing Group (Bloomsbury Publishing).

Van Avermaet, P. \& Gysen, S. (2008). Language learning, teaching and assessment and the integration of adult immigrants. The importance of needs analysis. Council of Europe.

Vertovec, S. (2007). Super-diversity and its implications. Ethnic and Racial Studies, 30(6), 1024-1054.

Willis, J. (1996). A flexible framework for task-based learning. Challenge and change in language teaching, 52-62.

Zhang, F. (2012). Computer-enhanced and mobile-assisted language learning: emerging issues and trends. Hershey, USA: IGI Global. 